\title{
SUSTAINABLE MANAGEMENT IN SPORT
}

\section{Yarmoliuk Olena ${ }^{1}$}

DOI: https://doi.org/10.30525/978-9934-571-89-3_76

Sport, in all its forms and activities, influence an environment. Additionally, sport is also interwoven in culture and society and the sports industry can use unique influence to provide much-needed business leadership in ecology and sustainable practices. The tangible effects of sports organizations environmental actions as to Casper J. M., Pfahl M. E. (2015) can help in supporting public health, reducing pollution, protecting habitats, saving energy and water, environmental behavior change in sport fans' lives, and far beyond. These effects have initiated a sport environmental movement with two broad goals: to reduce the ecological footprint of sports activities and to exploit the popularity of sports to raise environmental awareness in general [1, p. 3].

Power of sport, as one of the important drivers of promoting sustainable development, is supported by the results of numerous scientific research in ecology, management and economics. Many organizations from governmental, public, and business sectors pay attention to sports, as a tool capable of making a positive contribution to overcoming the most acute challenges of humanity, such as strengthening peace, protecting the environment, protecting human rights and freedoms.

As it was stated in 2030 Agenda for Sustainable Development, sport is also an important enabler of sustainable development. We recognize the growing contribution of sport to the realization of development and peace in its promotion of tolerance and respect and the contributions it makes to the empowerment of women and of young people, individuals and communities as well as to health, education and social inclusion objectives [2, p. 10].

Ensuring a balance between the nature opportunities and the needs of sports organizations has determined the necessity of implementation of the environmental management in $1980^{\text {th }}$ that is also based on sustainable development principles [3, p. 54].

A concept of sustainable development appeared in the 1970s in the frames of environmental protection and prevention of the ecological problems, which were

${ }^{1}$ National University of Ukraine on Physical Culture and Sport, Ukraine 
caused by rapid growth of population, ineffective industrial management, increased transport systems, uncontrolled and excessive use of natural resources. Sustainable development has been defined in many ways, but the most frequently quoted definition is from Our Common Future, also known as the Brundtland Report: "Sustainable development is development that meets the needs of the present without compromising the ability of future generations to meet their own needs" [4].

The challenges came along with such mega sport events as the Games of the Olympiad and Winter Olympic Games, Youth Olympics, World and European Championships, World Universiades were considered in the same perspective. To host Games, plan and maintain huge infrastructure of numerous sports and public facilities, organize accommodation, catering and social program for a large number of athletes, journalists and visitors the implementation of a sustainable management is necessary.

Sustainable development is a holistic concept that includes the idea of planetary boundaries, which, if exceeded, could cause irreversible damage to natural systems, along with the social and economic issues of human rights and minimum standards for living; in between the two is a space where humankind can continue to develop without abusing the environment. As a management concept, sustainable development balances environmental, social, and economic aspects in decision-making processes. The other factor of vital importance in defining sustainable development is time; our management actions now must project far into the future [5, p. 17].

Sustainable management in sport (SMeS) is the approach that allows ensuring environmental safety, social benefits and profitability of a sports organization based on the sustainable development. Growing environmental concerns, coupled with public pressure and stricter regulations, are changing the way sport do business across the world. Sport is on a three-stage journey from ecological management, through environmental risk management; to long-term sustainable development strategies (see Figure 1).

The following fundamental principles could be applied to the SMeS:

(1) The economic efficiency as the ability of using nature and human resources for sports industry with the positive feedback for environment and society (line $\mathrm{X}$ at Figure 1).

(2) The environmental footprint as the priority of environmental objectives while hosting sports events, maintaining sports facilities and managing sports industry (line $\mathrm{Y}$ at Figure 1).

(3) The social imperative as the priority of human needs in safe environment and high standards of living and engaging in sports activities (line $\mathrm{Z}$ at Figure 1).

In the initial phase of the journey, the need to comply with environmental regulations drives improvements in eco-management. Sport businesses adopt a more proactive approach in the next phase. Environmental risk management is introduced, to reduce environmental liabilities and to minimize the costs of regulatory compliance.

Some sport organizations recognize that the implementation of sustainable business strategies can lead to new opportunities and improved results - the sustainable management phase. 


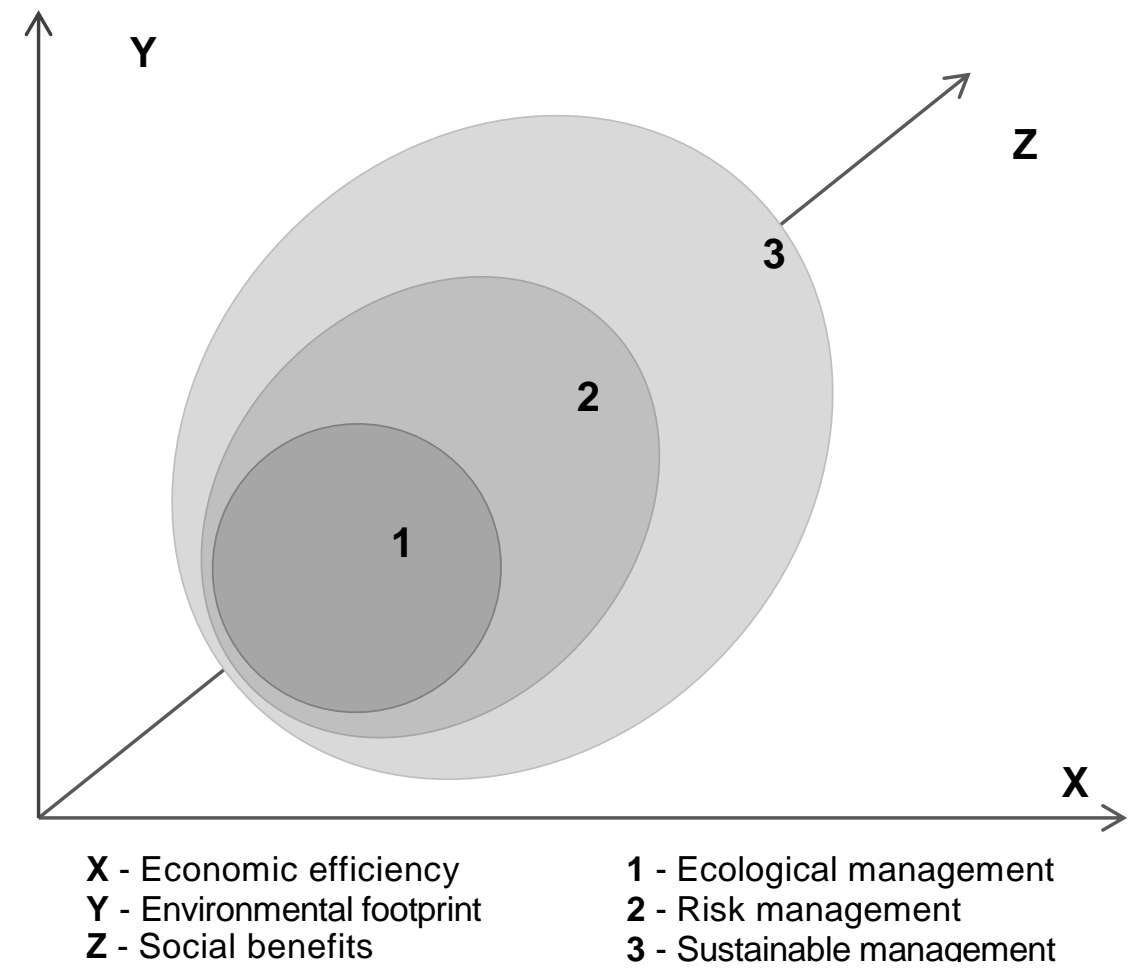

Figure 1. Homology field of sustainable management in sport

Today's sport sector is increasingly emphasizing the concept of sustainability and incorporating a triangle of economic, environmental and social approaches when making management decisions about legacy and development. As sports organizations all over the world face the challenges of sustainability, there is an increasing need for leaders who have the capacity to incorporate strategies for both sustainability and profitability into their businesses to achieve value maximization in a more holistic way. With environmental issues such as global warming, pollution and the depletion of natural resources threatening our existence, sports organizations must learn to reduce, reuse and recycle in order to protect our planet while taking care of people and maximizing outcomes. Sustainable management in sport is a brand new approach that looks beyond short-term profits, and focuses on long-term gain by incorporating the environmental and social costs of doing business into strategic management plan.

\section{References:}

1. Casper J. M., Pfahl M. E. (2015). Sport Management and the Natural Environment: Theory and Practice: Theory and practice. NY: Routledge.

2. 2030 Agenda for Sustainable Development: UN A/RES/70/1: paragraph 37, 2015, 35 p. Retrieved from: https://www.un.org/en/development/desa/population/migration/generalassembly/ docs/globalcompact/A_RES_70_1_E.pdf (accessed 31 March, 2019).

3. Imas Je.V., Ctighanenko O.I., Futornyj S.M., Jarmoljuk O.V. (2018). Ekologhija sportu: monoghrafija, Kyiv: Olimpijsjka literatura (in Ukrainian).

4. Sustainable development: International Institute for Sustainable development. Retrieved from: https://www.iisd.org/topic/sustainable-development (accessed 29 March, 2019).

5. McCullough B., Kellison T. (2018). Handbook on sport and the environment. NY: Routledge. 